\title{
中国交法の用語
}

高橋君平

敞密に規定された用語を瞅駛せぬと文法

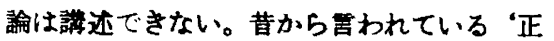
名”名をただす，とは文法諭では「用語を正 確に規定する」といらことに外ならぬ。

二千年来，文法用語がなかったといら事実 により中国古典の伝注硫には文法論はないと 栕婨できる。

20世䄫以降，欧米文法論の影行むむて， 黎錦孯，楊樹達、王力，呂叔湘、高名额、楊伯 岥、周法高，張志公……踷公によって漠語文 法は梨踽的に進歩したが，いまなお gene・ rativeに慗成できないのは，次の 2 つの久 陥が残されているからでないだろら。

1. 実辞 (主要語) と虚辟（付加語）を区别 しない。

2. 中国語の文型全部を漏れなく抽出してい、 ない。

ところが近年来, 中国科学院語言研究所や 北京語言学院蹋「中国語教科書」などはここ の 2 点を棚上げしたまま，別に「葆雑調語」

「能願動詞」などといら用語を新造し，今て はこの 2 語を引用せぬ文法論はない、どであ る。しかし趴見によれば,この2語はど雑駁 不明確な用語はない。その粗雑ゆえにこの 用語は文法論を更に混乱させ，その進歩を阻 碍するものゆえ, 断乎として排粠抹殺してし まわねばならない。

\section{I衫雑訶铻 複雑なる謂語}

複雑なる謂語とは一体何か。被雑なる， とは複雑ならさるるのの対称だから，なるも

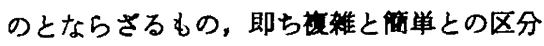
を先ず明嘕にしなければならないがそのた めには「简単謂語」を規定することから始め なければならない。しかし文法家はそれをや つていない。これでは「就䧴謂語」は始めか ら成り立ちよらがないではないか。
呂算平氏の「複婎謂羓」に上ると，一句の 内に别詞または形容詞が二つ以上述語になっ ているむの，と定義しているが，ただそれた

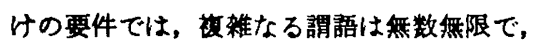
到底有限少数の類型に俩納できるむのではな い。

吕氏はA類 6, B 類 4, C 類 2，D類 3， 計15型を類別しているが，句そのむのの梅造 を規定していないから，その分類は雑駁で

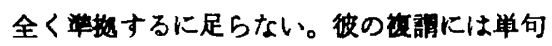
あり袮句あり，その単句には単述の情意勳詞

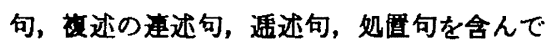
いるが，同じ䅡型の致使式，被较式などは却 って排除している始末である。いま呂氏の 「䫓䚴」から例文を引いてみると，

$1 \mathrm{~A}$ 類 (8) (1)你先上炕, 暖和暖和, (2) 我告訴你。君はまあ炕にあがうて䁔たまり 給え，铔は君に話そ5。

(1)は主語 “你” に上炕，䁔和，の 2 述語が

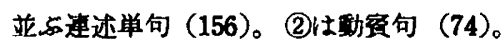
(1)(2)は併世て第句 (179)。

4 A (24) 我还有話要同你栨哩。私はま だ君に言わねばならら話がある。

'話' を兼語とする甶述単句 $(123,127)$

5 A（8）他看了很不舒服。彼はみて, たいへん不愉快。看, 之舒服（形容詞つ表 語) と 2 速述単句。1 A 8 と同型

同 (22) 她走起路来々小檫魚似的。彼は 道を歩き出した，小さい境みたいに。主川 動 | 容 〔補つ補語ある動赛句。B 2 と同じ この句は述語動詞は ‘走起”一つしかないの になぜ裉謂というのか。「述語が 2 つ上」 と自ら定めた条件に合わないではないか。こ

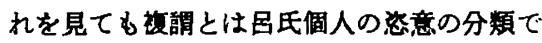
信盗するに足らないことがわかる。まだ起 来”を「势向㽖詞」といらのむ誤る。起，は いま走に後付して“走起”といら连合動詞と 


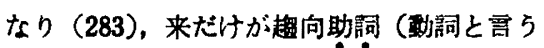
ベざない）である（289）。

2 B （18）我只可燐她没有知識。私はた だ彼が知識のないのを蟏れむばかり。

可僯、は情意動詞 (81)，她没有知識，は

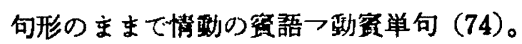
$3 \mathrm{~B}$ （11）你們=選|我\|当|隊辰，君5

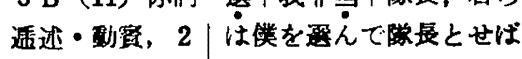
述語の並々速述（我を兼語とする违述形） 単句。 5 A 8 と 就得十听!我战話。情の 同型。

言らことを㷁かねばなら

同（16）人称她霊芝姑娘。人は彼を䨝芝

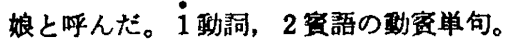

1 勒詞たかから攱謂の定辀に合わない。

以上7例は客钼要件によって句の橉造を分

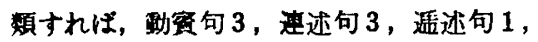
に龽納され，全部学句であるが，1Aだけは (1)(2)を併せて 1つの複句である。またこの 7 例の内には（1）述語が一つのものが 2 句あ ク，(2)等しく 3 B 類である（11）は逓述形 の述語を含む連述句，（16）は二つの空語の ある単述の動䆩句で, 粸造は全く異る。

呂氏の「複謂」4 類 15 型のらちいま 2 類 （A・B） 5 型を見ただけでも，むらこれた けの不都合を指摘できる。だから「復謂」な るものは呂氏がただ主钼的にそ5思5，とい らだけことで，われわれが納得できる客䙉 要件が些しる示されていない。皆がどらして こ5い5用語にゴマ化されているのか侵には 理解できない。公羊伝以来のことだが，あち らでは理屈をでっちあげるこが得意な学者 が時ふある。大陸で雷らことたからとて瓶吞 みにせず，必子自ら検証吟味してからのこと にしてはしい。遠感していては学問は進歩し ない（句末の（）は「句をきめ手とする中 国語文法」の頁)。

II 能願勤呞 可能や願望を表わす動詞 これる文法を混乱させる用語たから複謂と ともに抹般しなければならない。

動詞をその表わす意味によって分類すれ ば, 可能動詞, 願望動詞, 行動䡃詞, 思考〜,
衣食一，住行，学習，教育，芸能，恋要 趿硬，……から更に細分すれば結局，個々の

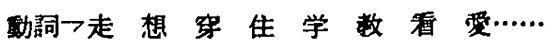
にまで行きつかねば納まりがつかなくなる。 これではしかし交法論の指向と目的に反し， 分類の意味がなくなってしまう。文法論は無 数慜限の莱材を有限少数の類型に集約省納す る作業でないだろらか。然らばそれに逆行す

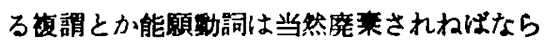
ない用語となる。

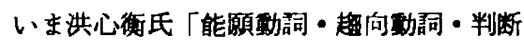
句」から，その不都合を指摘してみよ5（符 号・篓語はともに論者に由る)。

1. 洪氏は能願動詞として次の4程を兴け る :

1. 能 能够 会 可以 可能 得 (de)

2. 応応该 応当該

3. 須 要 須要 必須 得 (dei)

4. 願意 願 情願 要 肯 敢

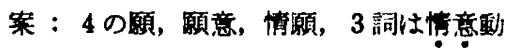
詞といら等殊な動詞だが，その他は全部助動 詞で動詞ではない。彼らが黎氏以来の䡒用器 一助動詞を抹殺したことは甚たしい錯覚。

2. 洪氏は能願動詞を立てる理由を8つあげ る :

1）単独で述語になる。

你敢嗎? 君は敢てするか?

案：たたここれだけで，敢の後に趿同がない し，前後文むないから，何を敢するのか文義 不通となり，この句は成り立たない。即ち単 独の敢だけでは述語にならない。

2 ）単独で質問に答えられる。

你敢去婜?一一敢。君は思いきって行く か,ひるまず〔行く〕。

案：いま問句に去動闹が出ているから，答 句は重複を捬って怔詞を省略した形。間句が 先行せぬなら, 敢一周の签句は成立しないこ とは( 1 )の場合と同じ。またこらいら省咯は 决して能願動詞の特性ではない。例えば你吃 飯还是吃面?には飯または面といら一字の名 詞で答えることができる。普通の交法である。

3) 正 (肯)反(否)を並へて筷間を表わす。 他会不会!再来。彼はきっとまた来ます 
か。

案：别詞 “来”が後続しなければこの句は 成立しない。他会不会, 他会不会再, では何 が会不会なのかまるでわからないから句にな らない。即ら能願動詞たけでは正反を並べて む問句になるとは言えない。訲詞が後続し ないと句義が通じないといらことは，会不会 が助险である証拋なのである。また正反結 構が策問になるのは能動の特性ではなく， あらゆる用吾に共通の性算である。例えば： 好不好, 是不是, 去不去, 吃不吃……仕可能

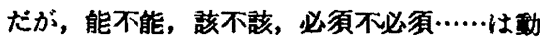
詞が後読しない限り交義不通で句にならな W。

4) 重量できない。

案：動詞はすべて重些できるのに，能能， 敢敢, 会会, 応当応当, 肯肯……と言えない のはそれらが勤詞でない証拋。

5) 状態鿷詞着, 了, 過, を付帯して進 行や完成を表わすことができない。

案：着了過住詞・形容詞にしかつかない から，それが付かないのは乵詞でない証扰。 だから洪氏 5 頁の '我本来不会, 現在会了' 今まで出来なかったが，今ては出来るように なった。‘他昨天不肯, 今天肯了’昨日は不 承知たっったか今日は承知した。す会，肯はい、 ま普通の動詞に活用しているものと認めさる を得ない。こいらのを詞性の枟易といら が，漠字は原則としてすへて詞性は転易する のである(21)。

要, は最もよく勤詞に活用し, 副詞連詞に むなる。会，肯は上例のよらに稀に動詞に活 用する。不会|客他不会 | 俄文

6）動詞・形容詞の前に用いられ，名氞の 前に用いられない。

案：これもまた動詞でなく，助勤詞である 証拋。各々別の二つの峌詞が前後に並んで述 語になるといらことは中国語には絶対にな い。前のものが助陲詞であるか，でなければ 啳のものが介詞である。二つとも等価の動詞 ではあり得ない。

他們会来 は 会十来 助動詞十動詞 没有人敢去は没有 1 人二敢十去
天気依当冷了は庆当十令 寒くなる管 身体才能够健康 才了能够十健康 身体は それでこそ健康になり得る

7 ）動詞・形容詞の前に用いる。能, 会, 政，応該……などはそれを削除してる句は 依然として成立する。

案：これもまた6）と同棣，それが助動詞 であり，主要趿詞てない証拗である。だから それ（助動詞）を“抽去”してむ句は依然と して完整であり得る：

他們来 没有人去 天気泠了身体健康 逆に别呞を削除すれば句は成り立たない：

他門会 没有人敢 天気応当了身体能够 ここに助陻詞と㖶詞の相異が紛れなく明確に 現われる。

洪氏 5 頁は，ここで重要な発言をする：

我們希望下雨, とい5句で, 希望は能願動 詞でないから、それを削除すると我下雨， となら交義不通で句にならないと。

然らば 我願意下雨，で願意を削除すれば やはり文義不通となるから，願意もまた能願 動詞でないことになり，自らの主張と矛盾す るではないか。然り，願意，願，情願，は希 望，喜歅…...などと同格の情意動詞でもとも と能願動詞ではないのである。それを性質の 全く異る助動詞と抱き合わせて，一榚に能願

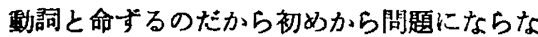
い。デタラメといら外はない。

8）能願動詞の後につつく詞語は“怎么 样”とい5問に答え得るものである。

案 : ナンセンスな要件だが，これもまた助 呀詞であることの証明になる。助動詞の効能 は，後続動詞の動作性を状隹性に転化するこ とである（199）。怎么样は状態を問ら述語た から，その答は当然状態となる。

写写 かく，かくといら動作を表わす 可以写写 かくことができる，状熊 去告新他 彼に話しに行く，動作 応該去告誩…行って話さねばならぬ，状熊

洪氏が「能動」の要件として提起した以上 8 項のうち，既にそれそれの項で霉及したよ $5 に, 1 ， 2 ， 3$ 項は動詞・形容詞にだけ可 
能なものであり，能愿動詞には当てはまらな い 4，5，6，7の4 項は期詞・形容詞で ない証明であり，8は助为閣である証明であ る。

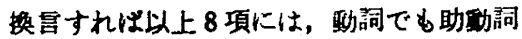
でもない能願動詞なるすのを特微つける要件 は一つもない。即ち洪氏の「能勒」なるもの

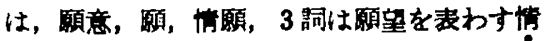

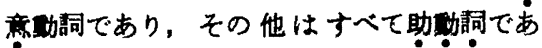

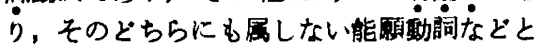
い5品詞は存在しないことを自ら籍露してい るのである。ここであらためて情意勒詞と助 動泀との相異を解説しておこら。

助趿詞 天要下雨 天川|要十下|雨 雨が るだろら，雨がふりそらだ ふりそらな状 想である。要は下につつく。ふりそ5。 他会説中文 他 || 会十説 | 中文 彼は中国 語を話せる。会は祱に先行する助勤詞で, “説中文”を窗語にとる動詞ではない。

情意功詞 我希望下雨 我川希旺：下|雨 私は雨がふるのを希吐する。希望は“下” につつくのではなく ‘下雨 あめがふる’

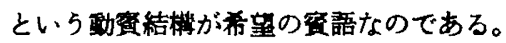
動詞| 竇語つ希呈|下雨。しかし下雨は名 詞ではないから“看|望”（名詞）などと区

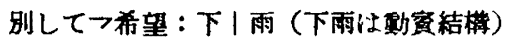
と分析する。い主希锞を ‘願意” に代替す れば，我川願意：下|雨 私は雨がふるこ とを願ら、雨ふりをこのむ，といらことに なる。

これによって，等しく‘下’勤呞の前に接

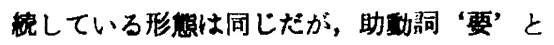
情意㲜詞 “願意”との性格は同じでないこと がよく理解されると思ら。

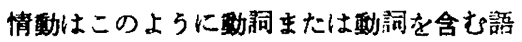
句を頞語にとるとい5特筫があるので，名詞 だけしか察語にとらない一般普通の珸詞つ看 吃，做，…学習，緱習，…..などと区别し て，われわれは情意敦詞と呼ぶ。情意や五官 のはたらきなどを表わす糼夙はみなこの一類 である（82）。別の例文を追加すると：

(1)她情願：剃了頭当姑子去。情願は剃につつ
くのではなく：以下全句をその璂語とする フ起を剃って尼になることを，心から願う。

(2)可是他不顆：将一切新新精神一篻捄䄫。 しかし彼は一切の新しい本柄や精神を抹殺 することを䫏わない。 洪心衡の14頁には次の例文がある：

(3)后庄上也有人願意:給小二黑跟小芹做媒人。 隣村には小二照と小芹のために仲人になる ことを碩ら（希望する）人むいる。

それから上神さんから数えられた 2 例：

(4)我願意: 敢十保证: 他一定作得好。彼がき っと上手にやっていることを，保証する ことを，願らつよろこんで保証したいと思 5。保証，も情䄭。

(5)他願意会弾吉他。川願意: 会十弾|吉他 ギターを弾けるよらになりたいと思5。会 は助的詞で咩につつく。ひくことができる。 博脸は取もよく用いられる。説, 知道, 想 ……のほかな敃数にあるがここでは見本 として以上数例を举げるに止めた（81〜85)。

文法諭は行詰りに来ているよらに見受けら れる。文法家は文法の原理を探求して準則を 開発する努力をしない。基盤を固めることな く、たた新説を打出そらと焦っているのでは

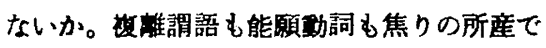
ある。根なしの草でなければ, 張り子の花で ある。ナぐにしほむか, やがて色あせ破れて しま5。中国新進学者の新説だからとて，す ぐに哌びつくのは考えもので, 必す自ら吟味 してみてからのことにしてほしい。

\section{【1文法用語の訳語}

中国文法の用語の要件は

1）日中共通とする

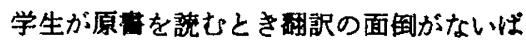
かりでなく、正確な理解を期し得る。

2) 惯用語を㦘用する

文法論はもら半世紀の歴史を絓て，用語は 相当定着している管たから，それを変更す るとか, 新語を設定するときは, 誰でも納 得できる明碓な玨由が公珰されればならな い。50年来埧用の「助㲜詞」を乘て，「雑 
調」「能功」を新設したのはみな鍇諧であ ることは，いま証明した通りである。

3）简単で 4) わかり易く 5) 区別が明 磪であること,などが考えられる。 名泀，代詞，数詞，是泀，形容詞，動泀， 副詞, 介泀, 連詞, 助㔚詞, 語気詞, 助詞, などはいまのままでいいだろら。

介詞を前㯰詞，連辞を綂詞と訳さなくて もよくかかるし，訳すと訳語の意味に制さ れて却って誤解を生ずる危険がある。

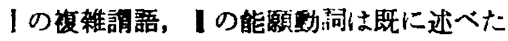
通り「不正名」だから廃裹する。趋向勒詞は 動詞ではなく助詞だから, 助詞に改め る。

主語, 述語, は黎掦王呂……単来の慣用語 だし，日本であ常識化しているからそのま ま。主 zhu と述 shuは同䫓で紛九易いから 近年中国では “謂 wei 棓’を常用するよらに なったのは自然のなり行きである。しかしイ ゴは音も漠字もひったりしないから，日本語 としては不邀当。

定語(テイゴ)・状語(ジョウゴ)・補語(ホゴ), はいみしくくし堅明な用語かな，と中国人のせ ンスにかねがね鄚服している。それを中国語 数科素が，(1)限定語, (2)状況語, (3)補足語, と翻訳するのは改悪で,一字を增して甜訳し ても，定義をつけねは意味がかから妨のは原 語と同じではないか。(1)(2)日本の文法用語 にもないのたから，訳語は用らべきでないと 思5。

(1)は連体篎飾語 (2)は連用佟飾語 (3)はや はり補足語か。日本のこ5いら長い文法用語

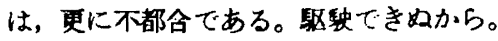

要するに中国語の文法用語は原則として翻 訳すべきでない。翻訳しても依然として漠字 語であり，文字が增すだけ不便となり，意味 に誤解が生じ易い。英独仏語は必す国語に翻 訳するからとて，中国語方外国語だから乘訳 せねばならぬと考えるのは，何とかの一つ覚 えというすのでないだろらか。
的, 即ち含法に説明できない。

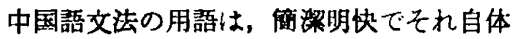
はたいへんよく出来ているが，その概念内容 の規定が粗雑であったり不明確であったりす るので用語の効果を充分に発揮することがで き如敦りでなく，途方もなく誤った結論を迹 く危倹があるものがある。「䙓謂」「能動」な ぞがその類である。

いまは用語の内容を絩密に規定しなおすこ とから始めることが絶対に必要であろら。

主語とは何か述語とは何か（以上主要語）。 定語とは, 状琵とは, 補語とは, 介詞とは, 各穆助同とは何か（以上付加語）等を弾密に 正確に規定すれば，句の權造は自ら明確とな ク，文法体系は自然に把㩧できるのではない たろらか。しかしそれを見つけ出し，それを 定義つけることは，简容易ではない。実は たいへん難しい仕费である。侵は20年遍歴し た。予想外に難しいものだから諸家はみなそ れを棚上げしたまま，或いはいい加減に触れ るたけけで前へ前へと進む。言らなれば基碄を 固めをに小屋組をしよらといらのである。ま ともな家が出来る筈がない。

いろいろの品詞名を負 5単語は前に誉げた 諸語を棈成する要件たが，品詞には実辞と虚 辟の相異があるとい5中国語の特性を誰もと りあけぬはは一体どらいら感覚だろら。介詞 と勤詞，副詞と形容詞を同一次元で諭じてい、 るよらでは中国語文法は沓久にものにならな いだろっ。

要するに中国語文法は基碟工秉を固めるこ とから始めなければならない。品詞では虚実 を区別し，句の棈造では主述と付加語を明確 に区分することである。いわゆる 名を正 す’のである。

さきに「雑謂」と「能動」は抹消すへし，

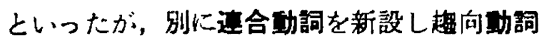
は进问助詞と改むへきたと思5。後日別稿で 皆さんの批判に供したい。

\section{IV むす ひ}

文法は敩密に規定された用語でないと合理

$$
\text { （昭和44年） } 1969-4-5
$$

